\title{
PEMETAAN HIGH ORDER THINGKING (HOT) MATEMATIS SISWA SEKOLAH MENENGAH PERTAMA SE-KOTA TASIKMALAYA
}

\author{
AA. Gde Somatanaya ${ }^{1}$, Depi Ardian Nugraha² \\ 1,2 Program Studi Pendidikan Matematika FKIP Universitas Siliwangi \\ email: aagdesomatanaya@gmail.com
}

\begin{abstract}
ABSTRAK
Penelitian ini dilatarbelakangi oleh pentingnya kompetensi atau kemampuan matematis dimiliki oleh setiap siswa, terutama untuk melanjutkan pendidikan pada jenjang yang lebih tinggi, digunakan dalam kehidupan sehari-hari di lingkungan masyarakat, atau untuk menunjang kebutuhan yang berkaitan dengan pekerjaan. Selain hal tersebut penelitian ini juga dilatarbelakangi oleh permasalahan sulitnya mahasiswa khususnya mahasiswa tingkat akhir memperoleh data yang akurat, terbaru, memiliki akuntabilitas yang bisa dipertanggungjawabkan dan yang paling penting mudah diakses untuk dijadikan dasar penelitian mahasiswa, terutama mengenai kemampuan berpikir matematis siswa. Banyak lembaga-lembaga penelitian seperti National Council Teacher Matematics (NCTM), Programme Internationale for Student Assesment (PISA), dll, yang sudah melakukan riset di bidang matematika, namun penelitian-penelitan tersebut tidak terfokus pada kemampuan berpikir matematis saja. Selain itu keterbatasan mahasiswa dalam mengakses hasil penelitian yang telah dilakukan oleh beberapa lembaga tersebut, yang menurut mahasiswa sulit. Hal ini yang mendorong peneliti untuk melakukan penelitian membuat peta kemampuan berpikir matematis khususnya kemampuan High Order Thingking (HOT) matematis siswa SMP SeKota Tasikmalaya. Tujuan dari penelitian ini adalah memberikan gambaran mengenai kemampuan High Order Thingking (HOT) matematis siswa SMP Se-Kota Tasikmalaya yang valid, up to date, memiliki akuntabilitas yang dapat dipertanggungjawabkan dan mudah diakses. Selain itu tujuan dari penelitian ini yaitu dapat dijadikan dasar penelitian lebih lanjut, baik oleh peneliti pada umumnya dan mahasiswa program studi pendidikan matematisa FKIP UNSIL pada khususnya. Kemampuan High order thingking (HOT) matematis merupakan kemampuan berpikir non-prosedural yang mencakup kemampuan mencari dan mengeksplorasi pola untuk memahami struktur matematis serta hubungan yang mendasarinya; kemampuan menggunakan fakta-fakta yang tersedia secara efektif dan tepat untuk memformulasikan serta menyelesaikan masalah; kemampuan membuat ide-ide matematis secara bermakna; kemampuan berpikir dan bernalar secara fleksibel melalui penyusunan konjektur, generalisasi, dan jastifikasi; serta kemampuan menetapkan bahwa suatu hasil pemecahan masalah bersifat masuk akal atau logis. Kemampuan High Order Thingking (HOT) matematis siswa penting dimiliki oleh setiap siswa yang belajar matematika di berbagai tingkatan sekolah, terkait dengan kebutuhan siswa untuk memecahkan masalah yang dihadapinya dalam kehidupan sehari-hari. Oleh sebab itu, kemampuan berpikir matematis terutama yang menyangkut doing math (aktivitas matematika) dan berpikir matematis tingkat tinggi perlu mendapatkan perhatian khusus dalam proses pembelajaran matematika. Luaran dari penelitian ini yaitu gambaran mengenai kemampuan High order thingking (HOT) matematis siswa SMP Se-Kota Tasikmalaya, tulisan berupa buku yang berisikan macam-macam kemampuan matematis yang termasuk level High Order Thingking (HOT) dan kajiannya beserta indikator-indikator ketercapaiannya, proseding pada seminar ilmiah berskala nasional, dan artikel untuk publikasi ilmiah dalam jurnal nasional terakreditasi atau jurnal internasional.
\end{abstract}

Kata Kunci: High Order Thingking, High Order Thingking of Matematics, Kemampuan generalisasi, berpikir kritis, berpikir kreatif, pemecahan masalah matematis, koneksi matematis, komunikasi matematis dan representasi matematis.

Dikirim: 25 April 2018; Diterima: 17 September 2018; Dipublikasikan: 29 September 2018

Cara sitasi: Somatanaya. A. G., dan Nugraha. D. A. 2018. Pemetaan High Order Thingking (HOT) Matematis Siswa Sekolah Menengah Pertama Se-Kota Tasikmalaya. Jurnal Teorema: Teori dan Riset Matematika. Vol 3 No 2, Hal 187194, September 2018. 


\section{Pendahuluan}

Penggunaan data yang valid, up do date dan memiliki akuntabilitas yang dapat dipertanggungjawabkan dalam sebuah penelitian menjadi hal yang wajib dilakukan untuk mengetahui hasil penelitian yang valid. Apabila berbicara mengenai data, data yang digunakan dalam penelitian ada dua jenis, ada data kualitatif dan data kuantitatif. Data kualitatif, yaitu data yang disajikan dalam bentuk kata verbal bukan dalam bentuk angka. Sedangkan data kuantitatif yaitu jenis data yang dapat diukur atau dihitung secara langsung, yang berupa informasi atau penjelasan yang dinyatakan dengan bilangan atau berbentuk angka. Sekaitan dengan jenis data tersebut, ada pula jenis data berdasarkan cara perolehannya yaitu data primer dan data sekunder. Data primer yaitu data yang langsung dikumpulkan oleh peneliti (atau petugasnya) dari sumber pertamanya. Sedangkan data sekunder yaitu data yang langsung dikumpulkan oleh peneliti sebagai penunjang dari sumber pertama, dapat juga dikatakan data yang tersusun dalam bentuk dokumendokumen.

Penggunaan data dalam penelitian baik data primer ataupun data sekunder sangat diperlukan dalam sebuah penelitian, termasuk penelitian yang dilakukan oleh mahasiswa, khususnya mahasiswa pendidikan matematika FKIP UNSIL yang sedang menyusun tugas akhir, salah satu kesulitan yang dihadapi mahasiswa dalam melaksanakan penelitian yaitu mendapatkan sumber data yang valid, terbaru dan memiliki akuntabilitas yang dapat dipertanggungjawabkan, meskipun sumber data tersebut merupakan data sekunder.

Banyak mahasiswa pendidikan matematisa FKIP UNSIL yang meneliti kemampuan berpikir matematis, terutama high order thingking matematis atau yang lebih dikenal dengan kemampuan berpikir matematis tingkat tinggi. Kemampuan berpikir matematis tingkat tinggi memang layak menjadi trendding topik yang diangkat untuk dijadikan fokus penelitian, sebab kemampuan berpikir matematis tingkat tinggi sangat banyak manfaatnya bagi siswa, terutama ketika siswa belajar matematika maka siswa tersebut diharapkan dapat memecahkan masalah yang dihadapinya baik di sekolah maupun dalam kehidupan sehari- hari.

Kemampuan berpikir matematis tingkat tinggi dapat dikembangkan melalui pembelajaran matematika sejak usia dini di pendidikan dasar dan menjadi tujuan yang harus dicapai oleh siswa setelah siswa tersebut belajar matematika. Sebagaimana tercantum dalam Standar isi Kurikulum 2013, Kemendikbud (2013) menyebutkan bahwa tujuan pembelajaran matematika di Sekolah yaitu agar siswa memiliki kemampuan sebagai berikut: (1) melatih cara berpikir dan bernalar dalam menarik kesimpulan, misalnya melalui kegiatan penyelidikan, eksplorasi, eksperimen, menunjukkan kesamaan, perbedaan, konsistensi dan inkonsistensi; $\quad$ (2) mengembangkan aktivitas kreatif yang melibatkan imajinasi, intuisi, dan penemuan dengan mengembangkan pemikiran divergen, orisinil, rasa ingin tahu, membuat prediksi dan dugaan, serta mencoba-coba; (3) mengembangkan kemampuan memecahkan masalah; dan (4) mengembangkan kemampuan menyampaikan informasi atau mengkomunikasikan gagasan antara lain melalui pembicaraan lisan, grafik, peta, diagram, dalam menjelaskan gagasan.

Hal senada juga disampaikan oleh Suryadi (2005: 37) bahwa pembelajaran matematika di sekolah memiliki peranan penting dalam mengembangkan kemampuan matematis siswa. Ada berbagai kemampuan yang bisa dikembangkan melalui matematika, seperti melatih cara berpikir bernalar, kreatif, kritis, berkomunikasi dan memecahkan masalah, dan sebagainya. Kemampuankemampuan tersebut dapat berkontribusi pada tiga dimensi kebutuhan anak yakni untuk melanjutkan pendidikan pada jenjang yang lebih tinggi, digunakan dalam kehidupan sehari-hari di lingkungan masyarakat, atau untuk menunjang kebutuhan yang berkaitan dengan pekerjaan.

Dikirim: 25 April 2018; Diterima: 17 September 2018; Dipublikasikan: 29 September 2018

Cara sitasi: Somatanaya. A. G., dan Nugraha. D. A. 2018. Pemetaan High Order Thingking (HOT) Matematis Siswa

Sekolah Menengah Pertama Se-Kota Tasikmalaya. Jurnal Teorema: Teori dan Riset Matematika. Vol 3 No 2, Hal $187-$ 194, September 2018. 
Berdasarkan pendapat Suryadi dapat disimpulkan bahwa seseorang setelah belajar matematika bukan hanya untuk mengembangkan kemampuan matematisnya saja, tetapi diharapkan dapat digunakan untuk kebutuhan hidupnya di masa yang akan datang, baik dalam kehidupan sehari-hari atau untuk melanjutkan pendidikan ke jenjang yang lebih tinggi.

National Council of Teacher Mathematics (NCTM, 2000) menetapkan bahwa terdapat 5 keterampilan proses yang perlu dimiliki siswa melalui pembelajaran matematika yang tercakup dalam standar proses tersebut, yaitu: "(1) problem solving; (2) reasoning and proof; (3) communication; (4) connection; dan (5) representation". Kemampuan-kemampuan tersebut termasuk pada berpikir matematika tingkat tinggi (high order mathematical thinking) yang harus dikembangkan dalam proses pembelajaran matematika.

Oleh karena hal itu sangatlah layak apabila kemampuan berpikir matematis tingkat tinggi memang layak menjadi trendding topik yang diteliti oleh mahasiswa program studi pendidikan matematika FKIP UNSIL. Adapun beberapa kemampuan berpikir matematis tingkat tinggi yang dimaksud dalam tujuan pembelajaran matematika adalah kemampuan berpikir nalar atau kemampuan generalisasi matematika, kemampuan berpikir kritis, kemampuan berpikir kreatif, kemampuan pemecahan masalah matematis, kemampuan komunikasi matematis dan kemampuan representasi matematis.

Berdasarkan latar belakang yang telah dipaparkan maka permasalahan yang muncul dalam penelitian ini adalah sangat minimnya data sekunder yang dapat dijadikan dasar bagi mahasiswa tingkat akhir untuk melakukan penelitian, terutama meneliti tentang kemampuan berpikir matematis tingkat tinggi pada siswa yang belajar matematika, khususnya siswa Sekolah Menengah Pertama di Kota Tasikmalaya. Oleh karena hal tersebut peneliti termotivasi untuk melakukan penelitian dengan tujuan untuk memberikan gambaran mengenai kemampuan High Order Thingking (HOT) matematis siswa SMP Se-Kota Tasikmalaya yang valid, up to date, memiliki akuntabilitas yang dapat dipertanggungjawabkan dan mudah diakses yang meliputi: kemampuan generalisasi matematis siswa; kemampuan berpikir kritis matematis; kemampuan kreatif matematis; kemampuan pemecahan masalah matematis; kemampuan komunikasi matematis; kemampuan koneksi matematis; dan kemampuan representasi matematis siswa SMP Negeri Se-Kota Tasikmalaya.

Permasalahan utama yang menjadi fokus dari penelitian ini adalah bagaimanakah gambaran mengenai kemampuan High Order Thingking (HOT) matematis siswa SMP Se-Kota Tasikmalaya yang valid, up do date, memiliki akuntabilitas yang dapat dipertanggungjawabkan dan mudah diakses. Permasalahan pada penelitian ini yaitu: (1) bagaimakah kemampuan kemampuan generalisasi matematis siswa SMP Negeri Se-Kota Tasikmalaya?; (2) bagaimakah kemampuan berpikir kritis matematis SMP Negeri Se-Kota Tasikmalaya?; $\quad$ (3) bagaimakah kemampuan kreatif matematis SMP Negeri Se-Kota Tasikmalaya?; (4) bagaimakah kemampuan pemecahan masalah matematis SMP Negeri Se-Kota Tasikmalaya?; (5) bagaimakah kemampuan komunikasi matematis SMP Negeri Se- Kota Tasikmalaya?; (6) bagaimakah kemampuan koneksi matematis SMP Negeri Se-Kota Tasikmalaya?; (7) bagaimakah kemampuan representasi matematis siswa SMP Negeri Se-Kota Tasikmalaya?. Hipotesis pada penelitian ini adalah kemampuan High Order Thingking (HOT) matematis siswa SMP Se-Kota Tasikmalaya berkategori cukup, berdasarkan standar penilaian kementrian pendidikan dan kebudayaan.

Pada penelitian ini dibatasi kepada kemampuan kemampuan matematika tingkat tinggi, yaitu kemampuan generalisasi matematis siswa; kemampuan berpikir kritis matematis; kemampuan kreatif matematis; kemampuan pemecahan masalah matematis; kemampuan komunikasi matematis; kemampuan koneksi matematis; dan kemampuan representasi matematis siswa SMP Negeri Se-Kota Tasikmalaya.

Dikirim: 25 April 2018; Diterima: 17 September 2018; Dipublikasikan: 29 September 2018 Cara sitasi: Somatanaya. A. G., dan Nugraha. D. A. 2018. Pemetaan High Order Thingking (HOT) Matematis Siswa Sekolah Menengah Pertama Se-Kota Tasikmalaya. Jurnal Teorema: Teori dan Riset Matematika. Vol 3 No 2, Hal 187194, September 2018. 
Tujuan dalam penelitian ini adalah untuk memmberikan pemetaan (gambaran) mengenai kemampuan High Order Thingking (HOT) matematis siswa SMP Se-Kota Tasikmalaya yang valid, up do date, memiliki akuntabilitas yang dapat dipertanggungjawabkan dan mudah diakses, yaitu kemampuan generalisasi matematis siswa; kemampuan berpikir kritis matematis; kemampuan kreatif matematis; kemampuan pemecahan masalah matematis; kemampuan komunikasi matematis; kemampuan koneksi matematis; dan kemampuan representasi matematis siswa. Selain itu tujuan penelitian ini juga dapat dijadikan dasar penelitian lebih lanjut, baik oleh peneliti pada umumnya dan mahasiswa program studi pendidikan matematisa FKIP UNSIL pada khususnya.

Hasil penelitian ini diharapkan bisa memberikan manfaat sebagai berikut: (1) pemetaaan (gambaran) mengenai kemampuan High Order Thingking (HOT) matematis siswa SMP Se-Kota Tasikmalaya pada tahun 2017; (2) buku yang berisikan macam-macam kemampuan matematis yang termasuk level High Order Thingking (HOT) dan kajiannya beserta indikator-indikator ketercapaiannya; $\quad$ (3) proseding pada seminar ilmiah berskala nasional; (4) artikel untuk publikasi ilmiah dalam jurnal nasional terakreditasi atau jurnal internasional.

\section{Metode Penelitian}

Metode penelitian yang digunakan adalah deskriptif kualitatif. Sugiyono (2010:15) menjelaskan bahwa metode penelitian deskriptif kualitatif merupakan metode penelitian yang berlandaskan pada filsafat positivisme, digunakan untuk meneliti pada kondisi obyek yang alamiah, (sebagai lawannya adalah eksperimen) dimana peneliti adalah sebagai instrumen kunci, pengambilan sampel sumber data dilakukan secara purposive dan snowball, teknik pengumpulan dengan trianggulasi, analisis data bersifat induktif/kualitatif, dan hasil penelitian kualitatif lebih menekan makna dari pada generalisasi. Berdasarkan pendapat di atas maka dapat disimpulkan bahwa penelitian deskriptif kualitatif yaitu suatu prosedur penelitian yang menggunakan data deskriptif berupa kata-kata tertulis atau lisan dari objek yang sedang dan dapat diamati. Penelitian ini berusaha menemukan gambaran atau peta tentang kemampuan High Order Thingking (HOT) matematis siswa SMP serta menyajikannya berdasarkan pengolahan data menggunakan aturan statistik deskriptif dengan bantuan program perhitungan statistik yaitu IBM SPSS versi 23. Penelitian ini merupakan penelitian deskriptif kuantitatif. Sugiyono (2010: 11) menyatakan bahwa penelitian deskriptif adalah penelitian yang dilakukan untuk mengetahui nilai variabel mandiri, baik satu variabel atau lebih (independen) tanpa membuat perbandingan, atau menghubungkan dengan variabel yang lain.

Penelitian ini diawali dengan mengkaji indikator HOT matematis dan Kompetensi Dasar/Kompetensi Inti pada kurikulum SMP. Kemudian tahapan berikutnya yaitu membuat instrumen penelitian, dan melakukan konsultasi dengan guru matematika SMP. Tahap berikutnya yaitu: Validasi instrumen penelitian untuk melihat face validity dan content validity, Validasi instrumen dilakukan kepada beberapa siswa SMP di Kota Tasikmalaya. Setelah dilakukan uji coba kemudian merevisi instrumen berdasarkan hasil uji coba instrumen (jika ada). Apabila instrumen tersebut sudah dinyatakan valid maka instrumen tersebut layak untuk digunakan secara empiris kepada siswa SMP Negeri se-Kota Tasikmalaya, yang kemudian hasilnya akan diolah dan dianalisis secara deskriptif dan inferensial menggunakan program statistik IBM for statistic version 23. Setelah dianalisis hasil penelitian tersebut diinterpretasikan dan dibuat gambaran mengenai pemetaan High Order Thingking (HOT) matematis siswa SMP se-Kota Tasikmalaya.

Dikirim: 25 April 2018; Diterima: 17 September 2018; Dipublikasikan: 29 September 2018

Cara sitasi: Somatanaya. A. G., dan Nugraha. D. A. 2018. Pemetaan High Order Thingking (HOT) Matematis Siswa

Sekolah Menengah Pertama Se-Kota Tasikmalaya. Jurnal Teorema: Teori dan Riset Matematika. Vol 3 No 2, Hal $187-$ 194, September 2018. 
Data kemampuan-kemampuan HOT matematis siswa SMPN se-kota Tasikmalaya dikumpulkan menggunakan instrumen tes matematis yang mencerminkan indikator-indikator kemampuan generalisasi matematis siswa; kemampuan berpikir kritis matematis; kemampuan kreatif matematis; kemampuan pemecahan masalah matematis; kemampuan komunikasi matematis; kemampuan koneksi matematis; dan kemampuan representasi matematis siswa SMP Negeri Se-Kota Tasikmalaya.

Instrumen dalam mengumpulkan data tentang kemampuan High Order Thingking (HOT) matematis adalah perangkat soal tes High Order Thingking (HOT) matematis berdasarkan dari indikator-indikator tiap jenis High order thingking (HOT) matematis yang disesuaikan dengan materi matematika atau KD matematika pada kurikulum SMP. Soal tes yang disusun terlebih dahulu dikonsultasikan dengan guru-guru matematika SMP. Selanjutnya dibuat kisi-kisinya. Tahap berikutnya dilakukan uji coba instrumen tes, uji coba dilakukan kepada siswa SMP di luar sampel penelitian.

Populasi penelitian ini adalah seluruh siswa Sekolah Menengah Pertama Negeri (SMPN) se-Kota Tasikmalaya baik kelas tujuh, kelas delapan, dan kelas sembilan, kisaran usianya 12-15 tahun. Pada kisaran usia tersebut menurut teori perkembangan mental Jean Piaget menyatakah bahwa pada usia tersebut anak berada pada tingkatan berpikir operasional formal (Budiningsih, $\mathrm{C}$. Astri, 2004: 39-40). Pada tahapan ini anak sudah mampu berpikir abstrak dan logis dengan menggunakan pola berpikir "kemungkinan". Model berpikir ilmiah dengan tipe hipothetico-dedutive dan inductive sudah mulai dimiliki anak, dengan kemampuan menarik kesimpulan, menafsirkan dan mengembangkan hipotesa.

Sampel penelitian diambil secara acak atau random yaitu satu kelas dari setiap Sekolah Menengah Pertama (SMP) se-Kota Tasikmalaya. Satu kelas tersebut adalah kelas IX dari setiap sekolah dengan pertimbangan berdasarkan standar isi kurikulum hampir semua Kompetensi Dasar (KD) atau Kompetensi Inti (KI) sudah tersampaikan oleh para pengajarnya.

Skor yang diperoleh dari jenis HOT matematis siswa berdasarkan penskoran yang ditransformasi ke dalam skor maksimal ideal 100. Setelah tes dilaksanakan, maka didapatlah skor masing-masing siswa. Skor tersebut dijumlahkan lalu dikonversi ke dalam bentuk nilai dan dianalisis. Langkah untuk menganalisis data hasil tes tertulis adalah menentukan nilai tes siswa dan menentukan kategori berpikir tingkat tinggi siswa sebagai berikut:

Tabel 1. Kriteria Kategori Penguasaan Kemampuan HOT Matematis Siswa

\begin{tabular}{rllc}
\multicolumn{2}{c}{ Interval Penguasaan } & Kategori Tingkat Penguasaan \\
\hline $85 \leq$ & $X$ & $\leq 100$ & Amat Baik \\
\hline $70 \leq$ & $X$ & $<85$ & Baik \\
\hline $50 \leq$ & $X$ & $<70$ & Cukup baik \\
\hline $0 \leq$ & $X$ & $\leq 50$ & Kurang baik \\
\hline
\end{tabular}

(Berdasarkan International Center for the Assesment of Higher Order Thinking)

Selanjutnya dari data tersebut disajikan menggunakan teori statistika deskriptif, untuk menghitung ukuran-ukuran statistiknya serta penyusunan tabel statistik.

Dikirim: 25 April 2018; Diterima: 17 September 2018; Dipublikasikan: 29 September 2018

Cara sitasi: Somatanaya. A. G., dan Nugraha. D. A. 2018. Pemetaan High Order Thingking (HOT) Matematis Siswa Sekolah Menengah Pertama Se-Kota Tasikmalaya. Jurnal Teorema: Teori dan Riset Matematika. Vol 3 No 2, Hal 187194, September 2018. 


\section{Hasil Penelitian dan Pembahasan}

Penelitian ini dilaksanakan kurang lebih selama satu semester, mulai dari kajian ilmiah tentang kemampuan berpikir matematis tingkat tinggi, menyusun instrumen tes, uji coba instrumen tes, sampai pada pengumpulan data penelitian. Pengumpulan data penelitian dilakukan dengan cara memberikan soal tes kemampuan berpikir matematis tingkat tinggi yang meliputi kemampuan generalisasi, kritis, kreatif, pemecahan masalah, komunikasi, koneksi dan representasi multipel matematis. Soal tes tersebut diberikan kepada seluruh sampel penelitian.

Tes dikerjakan oleh siswa secara individu. Penskoran yang dilakukan adalah sesuai dengan rubrik penskoran yang telah dibuat. Masing-masing indikator terdiri atas satu deskriptor. Skor maksimal per deskriptor adalah empat dan skor minimumnya adalah nol. Skor maksimal untuk soal pertama adalah delapan karena terdiri dari dua pertanyaan. Soal kedua diberi skor maksimal empat, soal ketiga diberi skor maksimal empat, soal keempat diberi skor maksimal empat, soal kelima diberi skor maksimal empat, soal keenam diberi skor maksimal empat, soal ketujuh diberi skor maksimal empat, soal kedelapan diberi skor maksimal empat, soal kesembilan diberi skor maksimal dua belas karena terdapat 3 pertanyaan, soal kesepuluh diberi skor maksimal empat, soal kesebelas diberi skor maksimal empat, soal kedua belas diberi skor maksimal empat, soal ketiga belas diberi skormaksimal empat dan soal keempat belas diberi skor maksimal empat. Total skor maksimal seluruh soal adalah 68.

Setelah semua jawaban siswa diperiksa dan diberikan skor sesuai rubrik penskoran, maka langkah selanjutnya adalah mengkonversikannya ke dalam skala 100. Setelah diperoleh nilai siswa, selanjutnya nilai tersebut dikelompokkan ke dalam lima kategori kemampuan berpikir tingkat tinggi yang dapat dilihat pada tabel berikut. 
Tabel 2. Perolehan Nilai Kemampuan Berpikir Matematis Tingkat Tinggi

\begin{tabular}{|c|c|c|c|c|c|}
\hline $\begin{array}{c}\text { Jenis } \\
\text { Kemampuan } \\
\text { Matematis }\end{array}$ & $\begin{array}{c}\text { Kategori } \\
\text { Tingkatan } \\
\text { Sekolah } \\
\text { (Hasil UN 2016) }\end{array}$ & $\begin{array}{l}\text { Rata-Rata } \\
\text { Skor } \\
\text { Mentah } \\
\text { (aktual) }\end{array}$ & $\begin{array}{l}\text { Rata-Rata } \\
\text { Skor } \\
\text { (skla 100) }\end{array}$ & $\begin{array}{c}\text { Rata-Rata } \\
\text { Skor Total } \\
\text { Kemampuan } \\
\text { matematik }\end{array}$ & $\begin{array}{c}\text { Kategori } \\
\text { Penguasaan } \\
\text { Kemampuan } \\
\text { HOT Matematik }\end{array}$ \\
\hline \multirow{3}{*}{ Generalisasi } & Tinggi & 29,31 & 83,74 & \multirow{3}{*}{64,43} & \multirow{3}{*}{ Cukup Baik } \\
\hline & Sedang & 20,78 & 59,37 & & \\
\hline & Rendah & 17,56 & 50,17 & & \\
\hline \multirow{3}{*}{ Kritis } & Tinggi & 20,67 & 82,67 & \multirow{3}{*}{73,54} & \multirow{3}{*}{ Baik } \\
\hline & Sedang & 17,80 & 71,20 & & \\
\hline & Rendah & 16,69 & 66,76 & & \\
\hline \multirow{3}{*}{ Kreatif } & Tinggi & 23,09 & 92,35 & \multirow{3}{*}{80,10} & \multirow{3}{*}{ Baik } \\
\hline & Sedang & 21,63 & 86,53 & & \\
\hline & Rendah & 15,35 & 61,42 & & \\
\hline \multirow{3}{*}{$\begin{array}{c}\text { Pemecahan } \\
\text { Masalah }\end{array}$} & Tinggi & 34,72 & 50,64 & \multirow{3}{*}{45,39} & \multirow{3}{*}{ Kurang Baik } \\
\hline & Sedang & 29,19 & 42,04 & & \\
\hline & Rendah & 30,17 & 43,50 & & \\
\hline \multirow{3}{*}{ Koneksi } & Tinggi & 12,64 & 52,68 & \multirow{3}{*}{47,01} & \multirow{3}{*}{ Kurang Baik } \\
\hline & Sedang & 11,43 & 47,62 & & \\
\hline & Rendah & 9,78 & 40,74 & & \\
\hline \multirow{3}{*}{ Komunikasi } & Tinggi & 12,16 & 64,00 & \multirow{3}{*}{63,31} & \multirow{3}{*}{ Cukup Baik } \\
\hline & Sedang & 13,03 & 65,89 & & \\
\hline & Rendah & 11,41 & 60,04 & & \\
\hline \multirow{3}{*}{$\begin{array}{c}\text { Representasi } \\
\text { Multipel }\end{array}$} & Tinggi & & 50,43 & \multirow{3}{*}{41,35} & \multirow{3}{*}{ Kurang Baik } \\
\hline & Sedang & & 40,68 & & \\
\hline & Rendah & & 32,95 & & \\
\hline
\end{tabular}

Berdasarkan data pada Tabel 2 maka diperoleh hasil bahwa tingkat penguasaan kemampuan generalisasi dan komunikasi matematis siswa SMP Negeri di Kota Tasikmalaya berada pada kategori cukup baik, sedangkan penguasaan kemampuan berpikir kritis dan kreatif matematis siswa SMP Negeri di Kota Tasikmalaya berada pada kategori baik.

Tingkat penguasaan kemampuan pemecahan masalah, koneksi dan komunikasi matematis siswa SMP Negeri di Kota Tasikmalaya berada pada kategori kurang baik, hal ini diperkuat dengan rata-rata dari ketiga kemampuan tersebut berturut-turut yaitu 45, 39, 47,01, dan 41,35 .

\section{Simpulan}

Berdasarkan hasil analisis dan pembahasan berkaitan dengan kemampuan berpikir tingkat tinggi (HOTS) siswa, dapat diambil beberapa kesimpulan sebagai berikut:

Pertama, siswa berkemampuan HOTS level sedang mampu mengidentifikasi ide utama, menganalisis argumen, dan menunjukkan kegunaan hal yang diketahui untuk menjawab beberapa soal, sehingga memiliki kemampuan analisis cukup baik. Siswa tersebut juga mampu memberikan

Dikirim: 25 April 2018; Diterima: 17 September 2018; Dipublikasikan: 29 September 2018

Cara sitasi: Somatanaya. A. G., dan Nugraha. D. A. 2018. Pemetaan High Order Thingking (HOT) Matematis Siswa

Sekolah Menengah Pertama Se-Kota Tasikmalaya. Jurnal Teorema: Teori dan Riset Matematika. Vol 3 No 2, Hal 187194, September 2018. 
penilaian terhadap solusi dan metode yang digunakan serta melakukan pengujian ulang untuk beberapa soal, sehingga memiliki kemampuan evaluasi cukup baik. Siswa tersebut juga mampu merancang cara pengerjaan dan menunjukkan jawaban benar untuk beberapa soal, sehingga memiliki kemampuan kreasi cukup baik. Pada kemampuan logika dan penalaran, siswa menuliskan konten jawaban, bukti serta alasan, dan kejelasan gaya bahasa dengan efektif, baik, dan logis dalam menyelesaikan beberapa soal tes kemampuan matematis tingkat tinggi.

Kedua, siswa berkemampuan HOTS level rendah kurang mampu mengidentifikasi ide utama, menganalisa argumen, dan menunjukkan kegunaan hal yang diketahui untuk menjawab semua soal, sehingga memiliki kemampuan analisis kurang baik. Siswa tersebut juga kurang mampu memberikan penilaian terhadap solusi dan metode yang digunakan serta melakukan pengujian ulang untuk semua soal, sehingga memiliki kemampuan evaluasi kurang baik. Siswa tersebut juga kurang mampu merancang cara pengerjaan dan menunjukkan jawaban benar untuk semua soal, sehingga memiliki kemampuan kreasi kurang baik. Pada kemampuan logika dan penalaran, siswa tidak mampu menuliskan konten jawaban, bukti serta alasan, dan kejelasan gaya bahasa dengan efektif, baik, dan logis dalam menyelesaikan semua soal tes kemampuan matematis tingkat tinggi.

\section{UCAPAN TERIMA KASIH}

Peneliti mengucapkan banyak terima kasih kepada :

1. Ketua LPPM Universitas Siliwangi

2. Dekan FKIP Universitas Siliwangi

3. Ketua Program Studi Pendidikan Matematika Universitas Siliwangi

4. Semua pihak yang telah membantu dan terlibat aktif baik secara moral maupun materil dalam pelaksanaan penelitian ini.

\section{DAFTAR RUJUKAN}

Budiningsih, C. A. (2004). Belajar dan Pembelajaran. Jakarta : PT. Rineka Cipta.

Kemendikbud, R. I. (2013). Bahan Pelatihan Kurikulum 2013.

National Council of Teacher Mathematics. (2000). Principles and Standards for School Mathematics. Virginia: NCTM.

Sugiyono, 2010. Memahami Penelitian Kualitatif. Alfabeta Bandung

Suryadi, D. (2005). Penggunaan Pendekatan Pembelajaran Tidak Langsung serta Pendekatan

Gabungan Langsung dan Tidak Langsung dalam Rangka Meningkatkan Kemampuan Berpikir Matematika Tingkat Tinggi Siswa SLTP. Disertasi pada PPS UPI Bandung: tidak diterbitkan. 